\title{
ANALYSIS ON THE DEVELOPMENT OF LEGISLATIONS GOVERNING SHARIAH ADVISORY COUNCIL OF BANK NEGARA MALAYSIA
}

\author{
Mohammad Azam Hussain ${ }^{1}$ \\ Rusni Hassan ${ }^{2}$ \\ Aznan Hasan ${ }^{3}$
}

\begin{abstract}
The establishment of Shariah Advisory Council under the aegis of Bank Negara Malaysia in 1997 was the best solution taken by the Government to harmonize the issue of divergence of Shariah opinions among the Shariah committees established by the Islamic banks and takaful operators. Since then, the Shariah Advisory Council has been regulated by several statutes which provide the legal framework of such a Council. Using a historical approach, this article highlights the development of the legal framework of Shariah Advisory Council since its establishment. Comparative analysis method is used to compare the existing legislation to the previous one. Finally, the article found that the Central Bank of Malaysia Act 2009 (Act 701) provides a comprehensive legal
\end{abstract}

1 Senior Lecturer, School of Law, College of Law, Government and International Studies, Universiti Utara Malaysia, Sintok, Kedah Darulaman, hmazam@uum. edu.my

2 Associate Professor, Ahmad Ibrahim Kulliyah of Law, International Islamic University Malaysia, Kuala Lumpur, hrusni@iium.edu.my

3 Associate Professor, Ahmad Ibrahim Kulliyah of Law, International Islamic University Malaysia, Kuala Lumpur, haznan@iium.edu.my 
framework to regulate Shariah Advisory Council compared to the previous statutes.

Keywords: Shariah Advisory Council, Shariah Advisory, Shariah compliance, Islamic finance, Central Bank of Malaysia Act 2009

\section{INTRODUCTION}

The Shariah Advisory Council (hereinafter referred to as "SAC") was officially established on $1^{\text {st }}$ May 1997 under the aegis of Bank Negara Malaysia (hereinafter referred to as "BNM"). The SAC is the highest authoritative body in ascertainment of Shariah matters relating to Islamic finance in Malaysia. ${ }^{4}$ In the early days, the establishment of SAC was based on three objectives. SAC acted as the highest authoritative body to advise BNM on Islamic banking and takâful business in Malaysia. The function of SAC is to co-ordinate Shariah issues on Islamic banking and financial business. This advisory body also had a role to analyse and to evaluate Shariah aspects of new products or schemes submitted by banking institutions. ${ }^{5}$ The establishment of SAC is capable of strengthening the Islamic financial framework in general and the Shariah advisory framework in particular.

Since the establishment of the SAC in 1997, the council has been regulated by several statutes beginning with Banking and Financial Institutions Acts 1989 (Act 372) (hereinafter referred to as "BAFIA"), Central Bank of Malaysia Act 1958 (Revised 1994) (Act 519) (hereinafter referred to as "Act 519") and Central Bank of Malaysia Act 2009 (Act 701) (hereinafter referred to as "CBMA"). In the initial stage, the SAC was regulated by BAFIA. Pursuant to BAFIA, BNM was required to establish $\mathrm{SAC}$ which was required to consist of such members, and to have such functions, powers and duties as may be specified by BNM to advise the bank on the Shariah matters relating to Islamic

4 Bank Negara Malaysia, Shariah Resolutions in Islamic Finance, (Kuala Lumpur: Bank Negara Malaysia, 2010), xv; Mohd Lukman bin Abdull Mutalip, 'Islamic Banking: Growth and Institutional Framework' in The Malaysian Financial System, ed. M. Fazilah Abdul Samad (Kuala Lumpur: University of Malaya Press, 2006), 8; Wan Marhaini Wan Ahmad, 'Islamic Banking in Malaysia' in The Malaysian Financial System, ed. M. Fazilah Abdul Samad (Kuala Lumpur: University of Malaya Press, 2006), 20.

5 Bank Negara Malaysia, The Central Bank and the Financial System in Malaysia A Decade of Change (1989-1999) (Kuala Lumpur: Bank Negara Malaysia, 1999), 251. 
financial business. ${ }^{6}$ BAFIA has provided an essential legal platform for the establishment of the SAC.

In 2004, the regulatory aspect of the SAC has been fully placed under Act 519 due to the amendment made by Central Bank of Malaysia (Amendment) Act 2003 (Act A1213). Act 519 has reinforced the role of the SAC and provided the legal recognition to this body as the highest authoritative body on Shariah matters relating to Islamic banking and financial business. ${ }^{7}$ In the same year, paragraph 124(7)(a) of BAFIA was also amended by Banking and Financial Institutions (Amendment) Act 2003 (Act A1211), which provided that the SAC be referred to the SAC established under subsection 16B(1) of Act $519 .{ }^{8}$

Section 16B of Act 519 provided certain matters related to the SAC including the requirement for BNM to consult the SAC on matters of establishment, procedure, functions, remuneration and allowances, secretariat to the SAC. There was also requirement for BNM to consult the SAC, in matters such as reference to the SAC for ruling from a court or arbitrator, request for consultation or reference for a ruling, effect of Shariah ruling made by the SAC and limitation to be appointed as member of the Shariah committee of IFI. ${ }^{9}$ All such matters have to be submitted to the Secretariat.

Beginning from $3^{\text {rd }}$ September 2009, the SAC is regulated by CBMA. In strengthening the regulatory framework of the SAC, several improvements have been made to CBMA. In terms of section arrangement, CBMA allocates the matters related to the SAC under Chapter 1 of Part VII (Islamic Financial Business). Act 519 put it under section 16B.

\section{LITERATURE REVIEW}

Prior to CBMA, SAC is regulated by BAFIA and followed by Act 519. Even though section $16 \mathrm{~B}$ of Act 519 has strengthened the regulatory framework of SAC, Zulkifli Hassan has commented that the Central Bank of Malaysia (Amendment) Act 2003 failed to resolve the issue pertinent to Shariah matters

$6 \quad$ Banking and Financial Institutions (Amendment) Act 1996 (Act A954), section 66.

7 Central Bank of Malaysia (Amendment) Act 2003 (Act A1213), section 4. The new section 16B (Establishment of Shariah Advisory Council) was inserted to Act 519.

8 Banking and Financial Institutions (Amendment) Act 2003 (Act A1211), section 9.

9 Act 519, section 16B. 
since the decision made by the SAC is only binding upon the arbitrator and not the court. ${ }^{10}$

Noor Inayah Yaakob et al., commented that the provision of subsection $16 \mathrm{~B}(8)$ which states that the court may ask the opinion from the SAC, causes the effect that the fat $\bar{a} w \bar{a}$ (Islamic legal opinions) given by the SAC is not binding on the civil court. It would be more appropriate if the fatāwa given by the SAC should bind the civil court as a guarantee that Islamic banking principles will not deviate from Shariah. ${ }^{11}$

Meanwhile, Mohammad Azam Hussain and Mumtaj Hassan based on their analysis on the approach of the courts in applying the provisions of section 16B concluded that different approaches were taken by the courts whether to refer to the SAC or not in deciding Shariah matters on Islamic financial business. $^{12}$

Ruzian Markom and Noor Inayah Yaakub ${ }^{13}$ have analysed the role of the SAC either as expert to ascertain or expert for determination of rulings on Islamic finance in Malaysia. The authors have compared the provisions pertaining to the SAC as provided under Act 519 and CBMA. Apart from that, the article also touched on the functions of the Shariah advisory boards of IFIs as provided by the statutes, guidelines, international standards and decisions of the courts. One of the important discussions made in the article pertains to the legal status of the SAC in Islamic finance dispute resolution. According to them, although CBMA upholds and binds the parties to the rulings issued by the SAC once a matter has been referred to the SAC, the law still provides for discretionary powers of the judge as may be required. A judge does not

10 Zulkifli Hasan, 'Sharia Governance in Islamic Financial Institutions and the Effect of the Central Bank of Malaysia Act 2009,' Journal of International Banking Law and Regulation (2010): 105-108.

11 Noor Inayah Yaakob et al., 'Perkembangan Undang-undang Islam Sejak Merdeka,' LNS (A), 1 (2011): xlii. CLJ Law Database <http://www.cljlaw.com.eserv.uum. edu.my>, accessed 3 January 2013.

12 Mohammad Azam Hussain \& Mumtaj Hassan, 'Peranan Jawatankuasa Penasihat Syariah dalam kes-kes Perbankan dan Kewangan Islam di Malaysia,' (Paper presented at International Conference on Corporate Law 2009, jointly organised by College of Law, Government \& International Studies, Universiti Utara Malaysia, Malaysia and Fakultas Hukum, Universitas Airlangga, Indonesia, 1-3 June 2009), $1-10$.

13 Ruzian Markom \& Noor Inayah Yaakub, 'Litigation as Disputes Resolution Mechanism in Islamic Finance: Malaysian Experience,' European Journal of Law and Economics, 19/2 (September 2013): 5. 
merely decide based on rulings provided by the SAC on an issue, he depends to a large extent on the judge's own understanding and perceptions on how he understands the principles of maslahah (public interest) and the role of mașlahah (public interest) in ensuring a fair outcome in the light of the SAC rulings issued. The wordings of section 56 of CBMA have been drafted in this manner for the purpose inter alia, to provide the judge with the liberty to exercise his discretionary powers in the best manner bearing in mind the principles of mașlahah (public interest) and Maqāșid al-Sharī'ah (the objectives and purposes of Islamic law). The article also points out several legal obstacles in adjudicating Islamic banking law. Such obstacles involve inadequacy of existing legal framework, legal documentations, competency of civil courts judges and matters relating to expert evidence. The article concluded that, the role of the SAC is merely expert to ascertain the rulings since the SAC has no judicial power over the matter.

Ruzian Markom et al., in another work, stated that under CBMA, the SAC has a wider scope of referral and is not merely confined to the issue of whether the matter at hand involves any element which is not approved by the religion of Islam. The article also compares the provisions contained in CBMA and Act 519 pertaining to reference to the SAC by courts. According to them, even though there is wider scope of referral granted to the SAC under paragraph $16 \mathrm{~B}(9)(a)$ of Act 519 , the final say must rest with the presiding judge. Accordingly, the court may not be bound by the opinion of the SAC. In contrast, CBMA restricts the power of the judge where the judge is subject to be bound by the decision or ruling made by the SAC when reference has been made. The judge could not go behind the documents/agreements before him and could neither check on the substance of it if the judge had made reference to the SAC. The authors also highlight the legal standing in the event of inconsistency of Shariah ruling made by the SAC and the Shariah advisory board of IFI. Since the CBMA clearly states that the ruling of the SAC shall prevail, CBMA has cleared the air of uncertainty and creates no opportunity for such conflicting ruling/advice to be rendered at all. ${ }^{14}$

In another article, Zulkifli Hassan and Mehmet Asutay have analysed the court's decisions on Islamic finance disputes in Malaysia. In their article, they comparatively analyse the provisions pertaining to the SAC as provided under Act 519 and CBMA. According to them, CBMA provides a clear and precise legal framework for Islamic finance, particularly regarding the legal status of

14 Ruzian Markom et al., 'Adjudication of Islamic Banking and Finance Cases in the Civil Courts of Malaysia,' European Journal of Law and Economics, 36/1 (August 2013): 21-22. 
Shariah resolution and the SAC as the highest authority on Islamic banking and finance. By analysing the Islamic banking cases, the authors concluded that, the decision of the courts shows that the SAC's deliberations or expert opinions are actually needed. There is no harm in the court seeking the SAC's view and indeed it could strengthen the court's reasoning and arguments in making the decision. Meanwhile the first motion made by the learned judge in the case of Tan Sri Khalid Ibrahim v. Bank Islam Malaysia Berhad to refer to the SAC indicates a positive development of the courts' attitude towards resolving mixed legal and Shariah issues in Islamic finance disputes. ${ }^{15}$

Siti Nurul Aziera Moharani and Aminuddin Mustaffa in their article have discussed the role of the SAC in dispute resolution process in Malaysia. The article comparatively discussed the approach of the court pursuant to provision of Act 519 and CBMA in referring to the SAC for its ruling. According to the authors, they found that the impact of the amendment of section 16B of Act 519 pertaining to reference to the SAC by court or arbitrator is very minimal. The decided cases show that many judges view the referral to the SAC as provided under such section as a matter of discretion rather than mandatory. Consequently, the courts, more often than not, have chosen not to refer the Shariah issues to the SAC. The authors also raised a significant question pertaining to provision of CBMA, that is, to what extent does the ruling of the SAC bind the court. Based on the case of Mohd Alias Ibrahim v. RHB Bank Bhd \& Anor [2011] 4 CLJ 654, the authors concluded that provisions which make it obligatory for the court to refer Shariah issues to the SAC as Shariah matters are actually meant to assist the judge to reach a just and fair decision. Meanwhile, the duty to decide the other issues pleaded by the parties is still left exclusively to a trial judge. ${ }^{16}$

Finally, in the case of Tan Sri Abdul Khalid Ibrahim v. Bank Islam Malaysia Bhd \& Another Case [2010] 4 CLJ 388, a number of matters relating to SAC provided in Act 519 are clearly explained by Rohana Yusuf $\mathrm{J}$ in her judgment dated $21^{\text {st }}$ August 2009. In this regard, it would be good to reproduce several parts of her judgment which are relevant to the SAC established under Act 519 as follows:

15 Zulkifli Hassan \& Mehmet Asutay, 'An Analysis of the Court's Decisions on Islamic Finance Disputes,' ISRA International Journal of Islamic Finance 3/2 (2011): 41-71.

16 Siti Nurul Aziera Moharani \& Aminuddin Mustaffa, 'Role of the Shariah Advisory Council (SAC) in Dispute Resolution Process: Perspective on Recent Case Development,' Malayan Law Journal, [2012] 6 MLJ, Ixxxvii-cii. LexisNexis Database, http://www.lexisnexis.com.eserv.uum.edu.my>, accessed 3 March 2013. 
"[15] ... Section 16B designates the SAC to be the authority for the ascertainment of Islamic law for the purposes of Islamic banking business, takaful business or Islamic financial business. Bank Negara, under s. 16B(7) must consult the SAC on Syariah matters relating to Islamic Banking Business, Takaful Business, Islamic Financial Business, Islamic Development Financial Business, or any other business which is based on Syariah principles. Bank Negara, may issue written directives to banks and Financial Institutions in relation to Islamic banking or Islamic financing businesses in accordance with the advice of the $S A C$. Its membership as determined under s. 16B(2) is made of members from related disciplines, besides Syariah scholars... "

[16] Unders. 16B(8), it is provided that in any proceedings before the court when a question arises concerning a Syariah matter, the court or the arbitrator may take into consideration any written directives issued pursuant to sub-s. (7) or refer such question to the SAC for its ruling...

[17] ... it is clear from s. $16 \mathrm{~B}$ that the SAC is the body empowered for the "ascertainment of Islamic Law for the purpose of Islamic banking business...". The legislature had intended the SAC to be a legally recognized body under the law to ascertain the Islamic law applicable to Islamic Banking and Finance. With such specific legislative provision it is obvious that the SAC is a body empowered and recognized under the legislation to issue ruling and direction on the applicable Syariah Law in Islamic Banking Business.

[18] To my mind there is good reason for having this body. A ruling made by a body given legislative authority will provide certainty, which is a much needed element to ensure business efficacy in a commercial transaction. Taking cognisance that there will always be differences in views and opinions on the Syariah, particularly in the area of muamalat, there will inevitably be varied opinions on the same subject. This is mainly due to the permissive nature of the religion of Islam in the area of muamalat. Such permissive nature is evidenced in the definition of Islamic Banking Business in s. 2 of the Islamic Banking Act 1983 itself. Islamic Banking Business is defined to mean, banking business whose aims and operations do not involve any element which is not prohibited by the Religion of Islam. It is amply clear that this definition 
is premised on the doctrine of "what is not prohibited will be allowed". It must be in contemplation of the differences in these views and opinions in the area of muamalat that the legislature deems it fit and necessary to designate the SAC to ascertain the acceptable Syariah position. In fact, it is well accepted that a legitimate and responsible Government under the doctrine of siasah-as-Syariah is allowed to choose, which amongst the conflicting views is to be adopted as a policy, so long as they do not depart from Quran and Islamic Injunction, for the benefits of the public or the ummah. The designation of the SAC is indeed in line with that principle in Islam.

[19] Having examined the $S A C$, its role and functions in the area of Islamic Banking, I do not see the need for me to refer this issue elsewhere though I am mindful that under s. 16B(7) I am not bound by its decision. From its constituents in s. 16B(2) the members are made of people of varied disciplines besides Syariah. This, I believe will enable the body to arrive at a well informed decision instead of deciding the Syariah issue in isolation..."

\section{COMPARATIVE ANALYSIS OF PROVISIONS REGULATING SAC UNDER ACT 519 AND CBMA}

CBMA has retained the provisions relating to remunerations and allowances to be paid to the SAC members. ${ }^{17}$ The requirement to establish the SAC's secretariat to assist the SAC in carrying out its functions is also retained. ${ }^{18}$ Relating to the establishment of the SAC, CBMA has retained the provision that requires $\mathrm{BNM}$ to establish the $\mathrm{SAC}$ which shall be the highest authoritative body for the ascertainment of Islamic law for the purposes of Islamic financial business. ${ }^{19}$ Even though the provision of CBMA is much simpler and does not specifically explain the forms of Islamic financial business compared to Act 519 , it is not an issue since CBMA uses "Islamic financial business" which covers the matters specified in subsection 16B(1) of Act 519.

Furthermore, the interpretation of the phrase "Islamic financial business" in section 2 of CBMA refers to any financial business in Ringgit or other currency which is subject to the laws enforced by BNM and consistent with the Shariah. Similarly, there is no issue in not mentioning Islamic financial business is

\footnotetext{
17 CBMA, subsection 53(4); Act 519, subsection 16B(5).

18 CBMA, subsection 54(a); Act 519, subsection 16B(10).

19 CBMA, subsection 51(1); Act 519, subsection 16B(1).
} 
supervised and regulated by BNM since the jurisdiction of the SAC is limited to Islamic financial business conducted by the IFI under the supervision of BNM. Hence subsection 51(1) of CBMA retains the jurisdiction of the SAC in all activities related to Islamic financial business which is supervised and regulated by BNM.

There is a slight change regarding the provision pertaining to procedures to be adopted by the SAC. Act 519 stipulated that the SAC shall determine its own procedure. ${ }^{20}$ Even though the provision remains, an amendment has been made which stipulates that the SAC may determine its own procedure in discharging its duties. ${ }^{21}$ Under CBMA, the word "shall" has been changed to "may". Accordingly, the SAC now has an option either to determine or not to determine the procedures to be adopted by them. Previously, such requirement was mandatory for the SAC to determine their procedures to be adopted in carrying out their functions.

In relation to the function of the SAC, CBMA provides more detail explaination of the functions of the SAC. This is a significant enhancement in clarifying the functions of the SAC which includes: ${ }^{22}$

a) To ascertain the Islamic law on any financial matter and issue a ruling upon reference made to it;

b) To advise BNM on any Shariah issue relating to Islamic financial business, the activities or transactions of the bank;

c) To provide advice to any Islamic financial institution or any other person as may be provided under any written law; and

d) Such other functions as may be determined by BNM.

Act 519 only stated that the SAC shall have functions as may be determined by BNM. ${ }^{23}$

Also retained is the provision relating to a qualified person to be appointed as the SAC member as well as the qualification needed. ${ }^{24}$ However, there is a difference involving the appointment process. According to Act 519, the SAC members are appointed by the Minister on the recommendation of BNM. ${ }^{25}$

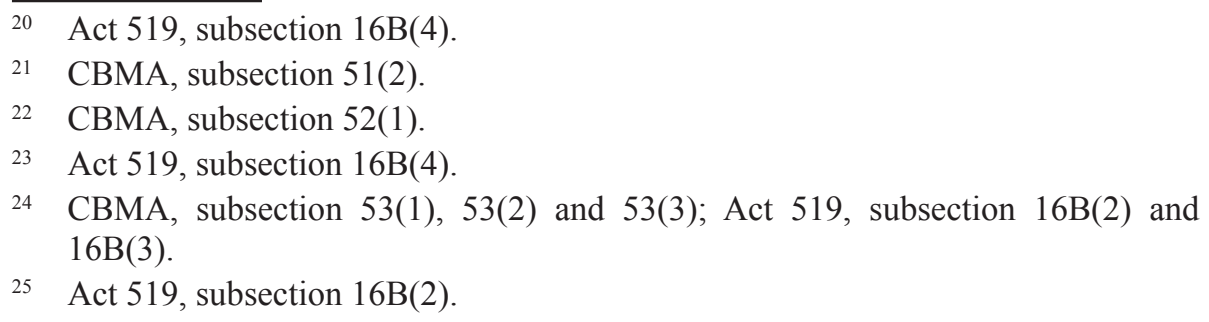


However, CBMA stipulates that the SAC members are appointed by Yang di-Pertuan Agong (the head of state of Malaysia) (hereinafter referred to as "YDPA") on the advice of the Minister after consultation with BNM. ${ }^{26}$

CBMA also requires BNM and the IFIs to consult the SAC in matters relating to Islamic financial business. Hence, the IFIs need to refer for a ruling or seek the advice of the SAC in Shariah matters. ${ }^{27}$ Unlike the previous Act, only $\mathrm{BNM}$ was required to consult the $\mathrm{SAC}$ in the matters relating to Islamic financial business. ${ }^{28}$

A provision which requires the court and arbitrator to refer to the SAC for a Shariah ruling in any proceedings relating to Islamic financial business, is maintained with some modification. According to Act 519, in any question that arises concerning Shariah matters in any proceedings relating to Islamic financial business, the court or the arbitrator may take into consideration any written directives issued by BNM or refer such questions to the SAC for its ruling. ${ }^{29}$ The word "may" in the provision gives the effect that reference to the SAC by the court or arbitrator is not a mandatory requirement. The court and the arbitrator have a choice either to adopt or not to adopt the alternatives provided by the law in deciding Islamic financial disputes.

In the case of Arab-Malaysian Merchant Bank Bhd v. Silver Concept Sdn. Bhd. [2006] 8 CLJ 9, in the High Court Malaya, Suriyadi Halim Omar J states that, pursuant to the provision of $16 \mathrm{~B}(8)$ of Act 519 , where in any proceedings relating to Islamic banking business before any court or arbitrator, whenever any question arises concerning a Shariah matter, the court may refer such question to the SAC. The court thus may even refer the matter to the SAC in the midst of any proceedings.

Hamid Sultan Abu Backer JC in the case of Malayan Banking Bhd $v$. Ya'kub Oje \& Anor [2007] 5 CLJ 311, states that, Islamic contract relating to commercial transactions is not only subject to the terms of the contract but must be decided subject to the Qur'anic injunctions and/or Islamic worldview as the case may be. In deciding such cases, the court can on their own motion decide the issue or alternatively call experts to give their views, pursuant to section 45 of the Evidence Act 1950 (Revised 1971) (Act 56) or pose the necessary questions to the SAC for their views.

\footnotetext{
26 CBMA, subsection 53(1).

27 CBMA, section 55.

28 Act 519, subsection 16B(7). Even though Act 519 does not stipulate such requirement, IFI is required to do so pursuant to section $13 \mathrm{~A}$ of the IBA, section 124 of BAFIA, section 129 of DFIA and subsection 53A(2) of TA.

29 Act 519 , subsection $16 \mathrm{~B}(8)$.
} 
Meanwhile, in the case of Arab-Malaysian Merchant Bank Berhad v. Silver Concept Sdn Bhd [2008] 9 CLJ 522, the court held that, once the determination is made by the SAC on the issue of Shariah compliance, any question on their determination can be referred to the SAC. However, reference to the SAC under section 16B of Act 519 is not mandatory. Meanwhile, the SAC's rulings are binding on the arbitrator when reference is made by the arbitrator. If reference is made by the court, the ruling issued by SAC is not binding the court but shall be taken into consideration in arriving at its decision. In this case, the issue is not pertaining to the Shariah compliance of the al-Bay 'Bithaman Ajīl (deferred payment sale) but the interpretation of its terms. Hence the court opines that reference to the SAC is not necessary.

In the case of Arab-Malaysian Finance Berhadv. Taman Ihsan Jaya Sdn Bhd \& 2 Ors; Koperasi Seri Kota Bukit Cheraka Berhad (Third Party) \& Another Cases [2009] 1 CLJ 419, Abdul Wahab Patail J decided that, in principle, the Islamic financing schemes approved by the SAC do not involve any element not approved by the Religion of Islam. Hence, there is neither necessity nor reason to refer to the $\mathrm{SAC}$ for any ruling. In addition, the court held that, even if the rulings of the SAC are to be taken into consideration in deciding Shariah issues, such rulings are not binding on the court.

The significance of referring the Shariah issues to the SAC has been highlighted in the case of Latifah Mat Zin v. Rosmawati Sharibun \& Anor [2007] 5 CLJ 253, in the judgment dated 25 July 2007. It explained that the establishment of the SAC under section 16B of Act 519 is for the purpose of the ascertainment whether a particular product of banking, finance and insurance (or takäful) is Shariah compliant or not.

In the case of Bank Islam Malaysia Berhad v. Lim Kok Hoe \& Anor \& Anothers Cases [2009] 6 CLJ 22, emphasized that the learned judge should not have taken upon himself to rule that the Bay 'Bithaman Ajīl (deferred payment sale) contracts were contrary to the Religion of Islam without having any regard to the resolutions of SAC of the BNM and the Shariah advisory body of Bank Islam Malaysia Berhad on the validity of Bay' Bithaman Ajül (deferred payment sale) contracts.

Although CBMA maintains almost the entire provision, the word "may" is replaced by the word "shall". ${ }^{30}$ Therefore for any question that arises concerning a Shariah matter in any proceedings relating to Islamic financial business, the court or the arbitrator should mandatorily either take into consideration any published rulings of the SAC or alternatively refer such questions to the SAC

30 CBMA, subsection 56(1). 
for its ruling. Meanwhile CBMA stipulates that the request for advice or a ruling of the SAC under CBMA or any other law shall be submitted to the secretariat similarly as stipulated under Act 519. ${ }^{31}$

Another significant improvement is pertaining to the effect of the ruling made by the SAC. According to the repealed Act, a ruling made by the SAC pursuant to reference made by the court or arbitrator shall be binding only on the arbitrator. Meanwhile, the court is not bound by the ruling made by the SAC. However the court shall take into consideration any ruling issued by the SAC upon reference to it made by the court in arriving at its decision. ${ }^{32}$ Once again, the provision gives a room to the court whether or not to follow the ruling made by the SAC.

In contrast, CBMA stipulates a more detailed explaination of the legal effect of the ruling made by the SAC. In this regard, ruling made by the SAC pursuant to a reference made by the IFIs, the court or the arbitrator shall be binding on the IFIs, the court or the arbitrator respectively. ${ }^{33}$

The case of Mohd Alias Ibrahim v. RHB Bank Bhd \& Anor [2011] 4 CLJ 654 is the first case decided by the court involving the CBMA since its implementation. In this case, the plaintiff raised the issue on the validity of sections 56 and 57 of CBMA. Pursuant to that, the court has to decide whether SAC has usurped the jurisdiction of the court and whether the court can abdicate its jurisdiction to make a decision to the SAC. The plaintiff also raised the issue pertaining to the right of the litigants to be heard and the breach of natural justice and procedural fairness. Another issue is pertaining to retrospective effect of sections 56 and 57 on the decisions made by the SAC.

Regarding the SAC, several significant points have been explained by the court. Regarding section 56 of CBMA, the word "shall" indicates the mandatory and binding effect. The court also stresses that the establishment of one supervisory authority is important to ensure that the development of Islamic financial instruments progresses smoothly and orderly. In addition, such supervisory authority should have the power to regulate a uniform interpretation of Islamic law within the sphere of Islamic finance and banking in the country and may choose the best opinion in its decision-making process after taking into consideration all of the authorities, customs of the locality etc. The SAC is the highest Shariah authority in Islamic finance in Malaysia.

\footnotetext{
31 CBMA, subsection 56(2); Act 519, subsection 16B(11).

32 Act 519, subsection 16B(9).

33 CBMA, section 57.
} 
The court also clarified that when reference is made by the court to the SAC on any Shariah matter, the SAC is merely required to make an ascertainment, and not determination, of Islamic laws related to the question. The SAC is not in a position to issue a new Hukm Syara ' (Shariah ruling) but to find out which one of the available hukm (ruling) is the best applicable in Malaysia for the purpose of ascertaining the relevant Islamic laws concerning the question posed to them. The SAC cannot be said to perform a judicial or quasi-judicial function since the process of ascertainment by the SAC has no attributes of a judicial decision. Apart from that, the court also clarifies that the rulings passed by SAC are not fatāwa (Islamic legal opinions) within the context of administration of Islamic laws in Malaysia. Such ruling can be considered to be an expert opinion with respect to Islamic finance matters and considered as collective ijtihād (juristic inference).

In relation to the significant function of the SAC in the ascertainment of Islamic law pertaining to Islamic financial business in Malaysia, Mohd Zawawi Salleh $\mathrm{J}$ in this case mentions that:

"[122] There is neither rhyme nor reason for the court to reject the function of the SAC in ascertaining which Islamic law to be applied by the civil courts in deciding a matter. Should this function be ignored, it would open the floodgate for lawyers and cause a tsunami of applications to call any expert at their own interest and benefit, not only from Malaysia but also other countries in the world which might not be familiar to our legal system, administration of Islamic law and local conditions just to challenge the Islamic banking transaction in this country.

[123] Allowing foreign experts to be called as witnesses to challenge the Islamic banking transaction in Malaysia will no doubt lead to increase in expense and the length of the proceedings."

Meanwhile in the case of Tan Sri Abdul Khalid Ibrahim v. Bank Islam Malaysia Bhd [2012] 3 CLJ 248, several issues have been raised pertaining to the legal aspects of the SAC pursuant to sections 56 and 57 of CBMA. Among the important findings by the court is regarding section 56. According to Mohd Zawawi Salleh J, it is clear that the SAC is required to ascertain the applicable Islamic law to the Shariah issues. Upon ascertainment of the Islamic law, the court would then apply it to the facts of the present case. Other important point is pertaining to the requirement to refer Shariah matters to the SAC. The judge further stated that, the non-binding effect under paragraph 16(B)(8) of Act 519 
had been taken away. The court also held that sections 56 and 57 of CBMA could be applied retrospectively.

The court also pointed out that the SAC is a statute-appointed expert with the task to ascertain the Islamic law for the purpose of Islamic financial business since the amendment of Act 519 in 2003 . Regarding the issue on the validity of sections 56 and 57, the court held that such sections are valid federal laws enacted by the Parliament of Malaysia. Accordingly, in dealing with Shariah issues, the court has to invoke section 56 of CBMA. Apart from that, the court has clarified that the SAC is not in a position to issue a new Shariah ruling, but only to find out which one of the available rulings is best applicable in Malaysia for the purpose of ascertaining the relevant Islamic law concerning the question posed to them. In addition, the SAC cannot be said to perform a judicial or quasi-judicial function. The function of the SAC is confined to the ascertainment of the Islamic law on financial matters. The court still has to decide the ultimate issues which have been pleaded.

Additional provisions are also inserted in CBMA. CBMA has clarified the meaning of the terms "ruling" which refers to any ruling made by the SAC for the ascertainment of Islamic law for the purposes of Islamic financial business. ${ }^{34}$ Similarly, relating to the appointment procedures of the SAC members, CBMA provides that the appointed members shall hold office on such terms and conditions as may be provided in their respective letters of appointment, and shall be eligible for reappointment. ${ }^{35}$ No such rules are provided in the repealed Act.

CBMA also provides the solution whereby whenever the ruling made by Shariah advisory boards constituted in Malaysia by IFIs is different from the ruling given by the SAC, the ruling of the SAC shall prevail. ${ }^{36}$ This is parallel to the function of the SAC as the highest authoritative body in the ascertainment of Islamic law pertaining to Islamic financial business. No such provision is provided under Act 519. Apart from that, CBMA now has no longer provision relating to restrictions on the SAC as stipulated under Act 519. Previously, the SAC members are not allowed to become a member of any Shariah committee, or act as a Shariah consultant or Shariah advisor, or assume any position or office to such effect, or occupy any office or employment, whether remunerated or not with any banking institution or other financial institution without prior written approval of BNM. ${ }^{37}$

\footnotetext{
34 CBMA, subsection 52(2).

35 CBMA, subsection 53(4).

36 CBMA, section 58.

37 Act 519, subsection $16 \mathrm{~B}(6)$.
} 
To facilitate the understanding, the following Table 1 summarizes the above comparison:

Table 1: Provisions Relating to the SAC under CBMA and Act 519.

\begin{tabular}{|c|c|c|}
\hline Items & CBMA & Act 519 \\
\hline $\begin{array}{l}\text { The Establishment of the } \\
\text { SAC }\end{array}$ & Subsection 51 (1) & Subsection $16 \mathrm{~B}(1)$ \\
\hline The SAC's Procedure & Subsection 51(2) & Subsection $16 \mathrm{~B}(4)$ \\
\hline Functions of the SAC & Section 52 & Subsection 16B(4) \\
\hline $\begin{array}{l}\text { Appointment of members } \\
\text { to the SAC }\end{array}$ & $\begin{array}{l}\text { Subsections 53(1) } \\
\text { and (2) }\end{array}$ & $\begin{array}{l}\text { Subsections } 16 \mathrm{~B}(2) \\
\text { and (3) }\end{array}$ \\
\hline Letter of appointment & Subsection 53(3) & No such provision \\
\hline $\begin{array}{l}\text { Remuneration and } \\
\text { allowances }\end{array}$ & Subsection 53(4) & Subsection $16 \mathrm{~B}(5)$ \\
\hline Secretariat to the SAC & Section 54 & Subsection 16B(10) \\
\hline $\begin{array}{l}\text { Requirement to the BNM } \\
\text { and IFIs to consult the SAC }\end{array}$ & Section 55 & $\begin{array}{l}\text { Subsection } 16 \mathrm{~B}(7) \\
\text { (Only requires } \mathrm{BNM} \\
\text { to consult } \mathrm{SAC} \text { ) }\end{array}$ \\
\hline $\begin{array}{l}\text { Reference to the SAC for } \\
\text { ruling from the court or } \\
\text { arbitrator }\end{array}$ & Section 56 & Subsection $16 \mathrm{~B}(8)$ \\
\hline $\begin{array}{l}\text { Request for consultation } \\
\text { or reference for a ruling } \\
\text { shall be submitted to the } \\
\text { Secretariat }\end{array}$ & Subsection 56(2) & Subsection 16B(11) \\
\hline $\begin{array}{l}\text { Effect of Shariah ruling } \\
\text { made by the SAC }\end{array}$ & Section 57 & Subsection $16 \mathrm{~B}(9)$ \\
\hline The SAC ruling prevails & Section 58 & No such provision \\
\hline $\begin{array}{l}\text { Limitation to be appointed } \\
\text { as member of the Shariah } \\
\text { advisory body of other } \\
\text { institutions }\end{array}$ & No such limitation & Subsection $16 \mathrm{~B}(6)$ \\
\hline
\end{tabular}




\section{CONCLUSION}

In summary it can be observed that from 1997 to 2009, the SAC is regulated by three different statutes namely BAFIA (1997-2004), Act 519 (20042009) and CBMA (2009 onwards). The evolutionary process carried out by the Government has enhanced the legal framework of the SAC. CBMA provides more conducive legal provisions in governing the SAC as the highest authoritative body in the ascertainment of Islamic law pertaining to Islamic financial business in this country. In addition, such improvement has strengthened the legal framework of the SAC in Malaysia. Finally, although the wording of the recent law seems to provide SAC a semi or quasi-judicial power, the civil court seems reluctant to accept this position.

\section{REFERENCES}

Bank Negara Malaysia, Shariah Resolutions in Islamic Finance (Kuala Lumpur: Bank Negara Malaysia, 2010).

Bank Negara Malaysia, The Central Bank and the Financial System in Malaysia - A Decade of Change (1989-1999) (Kuala Lumpur: Bank Negara Malaysia, 1999).

Mohammad Azam Hussain \& Mumtaj Hassan, 'Peranan Jawatankuasa Penasihat Syariah dalam Kes-kes Perbankan dan Kewangan Islam di Malaysia,' (Paper presented at International Conference on Corporate Law 2009, jointly organised by College of Law, Government \& International Studies, Universiti Utara Malaysia, Malaysia and Fakultas Hukum, Universitas Airlangga, Indonesia, 1-3 June 2009).

Mohd Lukman bin Abdull Mutalip, 'Islamic Banking: Growth and Institutional Framework,' in The Malaysian Financial System, ed. M. Fazilah Abdul Samad (Kuala Lumpur: University of Malaya Press, 2006).

Noor Inayah Yaakob et al., 'Perkembangan Undang-undang Islam Sejak Merdeka,' LNS(A), 1 (2011): xlii. CLJ Law Database http://www.cljlaw. com.eserv.uum.edu.my., accessed 3 January 2013.

Ruzian Markom \& Noor Inayah Yaakub, 'Litigation as Disputes Resolution Mechanism in Islamic Finance: Malaysian Experience,' European Journal of Law and Economics, 19/2 (September 2013).

Ruzian Markom et al., 'Adjudication of Islamic Banking and Finance Cases in the Civil Courts of Malaysia,' European Journal of Law and Economics, 36/1 (August 2013). 
Siti Nurul Aziera Moharani \& Aminuddin Mustaffa, 'Role of the Shariah Advisory Council (SAC) in Dispute Resolution Process: Perspective on Recent Case Development,' Malayan Law Journal [2012] 6 MLJ, Ixxxvii-cii. LexisNexis Database http://www.lexisnexis.com.eserv.uum. edu.my., accessed 3 March 2013.

Wan Marhaini Wan Ahmad, 'Islamic Banking in Malaysia,' in The Malaysian Financial System, ed. M. Fazilah Abdul Samad (Kuala Lumpur: University of Malaya Press, 2006).

Zulkifli Hasan, 'Sharia Governance in Islamic Financial Institutions and the Effect of the Central Bank of Malaysia Act 2009,' Journal of International Banking Law and Regulation (2010).

Zulkifli Hassan \& Mehmet Asutay, 'An Analysis of the Court's Decisions on Islamic Finance Disputes,' ISRA International Journal of Islamic Finance 3/2 (2011).

\section{Statutes}

Banking and Financial Institutions (Amendment) Act 1996 (Act A954).

Banking and Financial Institutions (Amendment) Act 2003 (Act A1211)9.

Central Bank of Malaysia Act 1958 (Revised 1994) (Act 519).

Central Bank of Malaysia (Amendment) Act 2003 (Act A1213).

Central Bank of Malaysia Act 2009 (Act 701).

\section{Cases}

Arab-Malaysian Finance Berhad v. Taman Ihsan Jaya Sdn Bhd \& 2 Ors; Koperasi Seri Kota Bukit Cheraka Berhad (Third Party) \& Another Cases [2009] 1 CLJ 419.

Arab-Malaysian Merchant Bank Berhad v. Silver Concept Sdn Bhd [2008] 9 CLJ 522.

Bank Islam Malaysia Berhad v. Lim Kok Hoe \& Anor \& Anothers Cases [2009] 6 CLJ 22.

Latifah Mat Zin v. Rosmawati Sharibun \& Anor [2007] 5 CLJ 253.

Malayan Banking Bhd v. Ya'kub Oje \& Anor [2007] 5 CLJ 311.

Mohd Alias Ibrahim v. RHB Bank Bhd \& Anor [2011] 4 CLJ 654.

Tan Sri Abdul Khalid Ibrahim v. Bank Islam Malaysia Bhd [2012] 3 CLJ 248. 
Jurnal Syariah, Jil. 23, Bil. 2 (2015) 325-342 